This manuscript is a preprint and has been submitted. This manuscript has not undergone peer review. Subsequent versions of this manuscript may have different content. If accepted, the final version of this manuscript will be available via the 'Peer-reviewed Publication DOI' link on the right-hand side of this webpage. Please feel free to contact any of the authors directly or to comment on the manuscript using hypothes.is(https://web.hypothes.is/). We welcome feedback! 


\title{
Controls on variations in minibasin geometries: Lower Congo Basin, offshore Angola
}

\author{
Zhiyuan Ge ${ }^{a *}$, Rob L. Gawthorpe ${ }^{\mathrm{a}}$, Leo Zijerveld ${ }^{\mathrm{a}}$ and Ayodeji P. Oluboyo ${ }^{\mathrm{a}, \mathrm{b}, \mathrm{c}}$ \\ ${ }^{\mathrm{a} D e p a r t m e n t ~ o f ~ E a r t h ~ S c i e n c e, ~ U n i v e r s i t y ~ o f ~ B e r g e n, ~ A l l e ́ g a t e n ~ 41, ~} 5007$ Bergen, Norway \\ ${ }^{\mathrm{b}}$ School of Earth, Atmospheric and Environmental Sciences, University of Manchester, Manchester, M13 \\ 9PL, UK \\ ${ }^{\mathrm{c}}$ PGS-Reservoir, Weybridge, Surrey, KT13 ONY, UK
}

Correspondence: Zhiyuan Ge, Department of Earth Science, University of Bergen, Allégaten 41, 5007 Bergen, Norway. E-mail: Zhiyuan.Ge@uib.no

\section{ABSTRACT}

In passive margin salt basins, the distinct tectonic domains of thin-skinned extension and contraction exert important controls on the geometry and evolution of minibasins. In this study, we use a semi-regional 3D seismic dataset from the Lower Congo Basin to investigate the spatial and temporal evolution of a network of salt-related minibasins and intervening salt walls and diapirs during thin-skinned salt tectonic deformation. Widespread thin-skinned extension occurred during Cenomanian to Coniacian created numerous normal faults, typically 5-10 km long and spaced 1-4 km apart within the supra-salt cover across the study area. Subsequently, during the Santonian-Paleocene, multiple, 10-25 km long, 5-7 km wide depocentres progressively grew and linked along strike to form elongate minibasins separated by salt walls that are several tens of kilometres long. Simultaneous with the development of the minibasins, thin-skinned contraction occurred in the southwestern downslope part of the study area, forming folds and thrusts that are up to $20 \mathrm{~km}$ long and have a wavelength of 2-4 km. The elongate minibasins further developed into turtle structures and the depocentres migrated towards the flanks of the minibasins during Eocene to Oligocene. From the Miocene onward, contraction of the supra-salt cover caused salt walls to be uplifted and created elongate and confined depocentres within the minibasins. Minibasin development is dependent on the kinematic domains in which they form. Distinct geometries develop due to extension, sediment loading and contraction. Variability in structural style and evolution within minibasins occurs due to along-strike growth of early formed depocentres. As minibasins have different subsidence rates and maturity, their geometry varies from one minibasin to another. Upslope migration of contraction further complicates the structural style and stratigraphic architecture of the minibasins. This study suggests that minibasin growth is variable both within individual minibasins as well as across the network of minibasins and is more complex than simple domain-controlled models of extension, translation and contraction would predict. 
Keywords minibasin, salt wall, salt tectonics, passive margin, Lower Congo Basin, Angola

\section{INTRODUCTION}

The dominant tectonic process in passive margin salt basins is gravity-driven, thin-skinned deformation. This is characterized by upslope extension and downslope contraction separated by a translational domain (e.g. Fort, Brun, \& Chauvel, 2004; Rowan, Peel, \& Vendeville, 2004). This configuration develops as a response to regional tilting, resulting from thermal subsidence and tectonic uplift, or basinward differential loading (e.g. Duval, Cramez, \& Jackson, 1992; Fort et al., 2004; Hudec \& Jackson, 2007; Lundin, 1992; Mauduit, Gaullier, Brun, \& Guerin, 1997; Rowan et al., 2004; Vendeville \& Jackson, 1992). Previous studies have shown that the upslope migration of the distal contractional domain may result in inversion of early extensional salt-related structures, forming squeezed diapirs (e.g. Fort et al., 2004). However, how minibasins respond to such contractional domain migration is not well understood.

Minibasins are remarkable morphological features in many basins underlain by mobile evaporites (e.g. Banham \& Mountney, 2013; Gemmer, Beaumont, \& Ings, 2005; Hudec, Jackson, \& Schultz-Ela, 2009; Jackson \& Talbot, 1991; Peel, 2014). The main driving force for minibasin formation has commonly been ascribed to the density contrast between the minibasin fill and underlying salt, where downbuilding of the minibasins is largely driven by sediment deposition which in turn generates more accommodation space for subsequent sedimentation by displacing the underlying salt (Hudec et al., 2009; Jackson \& Talbot, 1991). However, data from the Gulf of Mexico suggest that siliciclastic sediments at the time of, or shortly after, deposition are not dense enough to trigger the downbuilding process (Hudec et al., 2009). Along rifted margins, alternative triggering forces may include regional tectonics, either extension (e.g. Hodgson, Farnsworth, \& Fraser, 1992; Vendeville \& Jackson, 1992), or contraction (e.g. Hudec et al., 2009; Ings \& Beaumont, 2010), or sediment differential loading (e.g. Goteti, Ings, \& Beaumont, 2012; Peel, 2014). Only when the sediments are sufficiently buried and compacted, they become dense enough for the downbuilding process to occur and become the main control on minibasin development (Hudec et al., 2009). Therefore, multiple controlling factors should be expected to contribute to the development of minibasins during their evolution (Peel, 2014).

In this study, semi-regional extensive 3D seismic data covering a ca. $4000 \mathrm{~km}^{3}$ portion of the Lower Congo Basin (offshore Angola) (Fig. 1a) are used to document the structural style and tectono-stratigraphic evolution of a network of intraslope minibasins. The results show that the 
tectono-stratigraphic evolution of neighbouring minibasins can vary significantly due to changes of minibasin controls as well as different stages of minibasin maturation. Systematic variations in minibasin geometry provide helpful guidelines in understanding the changing controls on minibasin evolution in a passive margin setting.

\section{GEOLOGICAL SETTING}

The Lower Congo Basin is a $200 \mathrm{~km}$ long, N-S-striking salt basin that extends, from the coastline of Angola in the east, to the Angola escarpment at the base of Angolan slope in the west (Anka, Seranne, Lopez, Scheck-Wenderoth, \& Savoye, 2009; Cramez \& Jackson, 2000; Marton, Tari, \& Lehmann, 2000) (Fig. 1a). It is one of a series salt basins that developed along the west African passive margin associated with the breakup of Gondwana and opening of the Atlantic Ocean (Marton et al., 2000; Moulin et al., 2005; Nürnberg \& Müller, 1991). Late Jurassic to Early Cretaceous rifting was followed by an Aptian sag basin within which approximately $1 \mathrm{~km}$ of evaporites accumulated (Loeme Formation) (Anderson, Cartwright, Drysdall, \& Vivian, 2000; Anka et al., 2009; Brice, Cochran, Pardo, \& Edwards, 1982; Karner, Driscoll, McGinnis, Brumbaugh, \& Cameron, 1997; Marton et al., 2000; Valle, Gjelberg, \& Helland-Hansen, 2001) (Fig.2). Following deposition of the Loeme Formation, a shallow-water carbonate platform developed with near-shore siliciclastic sediments (Pinda Group) during the Albian (Anderson et al., 2000; Valle et al., 2001) (Fig. 2). Thin-skinned salt tectonics commenced by the end of the Albian, with normal faults that soled out in the salt in the upslope area, and contemporaneous folding and thrusting downslope (Fort et al., 2004; Marton et al., 2000; Valle et al., 2001). The shallow marine environment gave way to deep marine conditions during Late Cretaceous, leading to a transition to the mudstone-dominated Iabe Formation with turbidites deposited in slope and basinal areas (Anderson et al., 2000; Valle et al., 2001). Deep marine conditions with low sedimentation rates persisted into the Eocene, Landana Formation, until the ancestral Congo River began to supply larger volumes of siliciclastic sediments to the Lower Congo Basin from the Oligocene, resulting in an increase in gravity flow deposits in the Malembo Formation (Anderson et al., 2000; Anka \& Séranne, 2004; Valle et al., 2001). Higher sedimentation rates in the upslope area are thought to have enhanced thin-skinned salt-related extension (Duval et al., 1992; Marton et al., 2000; Valle et al., 2001). The formation of contractional structures in the distal area accelerated to accommodate the extension, leading to the development of the Angola Escarpment (e.g. Anka et al., 2009; Cramez \& Jackson, 2000; Fort et al., 2004; Rowan et al., 2004). 
In the Miocene, siliciclastic sediments of the deepwater Congo fan were largely trapped in the intraslope minibasins within the Lower Congo Basin, which filled in a complex fill-and-spill manner (Anderson et al., 2000; Anka et al., 2009; Oluboyo, Gawthorpe, Bakke, \& Hadler Jacobsen, 2014). Since the Pliocene, as the main discharge of the Congo river shifted north to its present location, the Congo fan also shifted away, to the north of the study area (Lavier, Steckler, \& Brigaud, 2001).

\section{DATASET AND METHODOLOGY}

This study utilized a proprietary, pre-stack, time-migrated 3D seismic survey, covering an area of approximately $4000 \mathrm{~km}^{2}$ on the Angola margin (Fig. 1a). The survey has an inline and crossline spacing of $50 \mathrm{~m}$ with a record length of six seconds two-way travel time (TWT). The data quality is generally excellent within the interval of interest but diminishes towards salt walls, often due to steeply dipping beds near the flanks of the salt structures. The display of the seismic data follows SEG normal polarity where a downward increase of acoustic impedance is represented by a peak and is shown in red. Two wells with conventional wireline log suites and proprietary, confidential biostratigraphic reports were used to calibrate the seismic interpretation and constrain the age of mapped horizons.

Stratal terminations, growth strata intervals and major changes of seismic facies were used to define nine regionally continuous and chronostratigraphically significant seismic horizons (Fig. 2). The base salt and top salt horizons delineate the salt layer of the Loeme Formation, allowing its thickness variations to be documented (Fig. 3). The base salt horizon is picked at the top of a group of parallel, continuous reflectors with moderate to high amplitude, marking the boundary between the salt and underlying strata (Fig. 2). Note that there is a severe velocity pull-up that affects the base salt horizon, and thus the sub-salt structure cannot be precisely constrained under the salt diapirs (e.g. Fig. 4). The top salt horizon is a high amplitude, locally continuous reflector but its continuity deteriorates over the steep flanks of salt structures (Fig. 2). The supra-salt cover strata, overlying the top salt horizon, are divided into seven units by six horizons (Fig. 2). Top Albian is a high amplitude, continuous reflector marked by local growth strata above and a group of sub-parallel and low amplitude reflectors below. It separates Albian carbonates from the overlying deepwater sediments (Fig. 2). The top Coniacian is picked at the top of a set of parallel, low amplitude reflectors that are marked by local onlap. Above this, top Paleocene delineates the top of a group of moderate to high amplitude reflectors usually associated with growth strata that converge towards structural highs. In contrast, the top Oligocene horizon is a relatively high amplitude, continuous reflector that bounds locally thickening strata above. The mid Miocene and 
top Miocene horizons follow the scheme of Oluboyo et al. (2014) subdividing and delineating the Miocene turbidite system (Fig. 2).

Two-way travel-time (TWT) structure maps and time-thickness maps (true vertical thickness), along with seismic cross-sections, were used to describe the structural style and tectonostratigraphy of the study area. Time-thickness maps were used to interpret variations in subsidence and structural activity at the time of deposition. Seismic interpretation was performed in the time domain and therefore geometric distortion, particularly adjacent to salt walls/diapirs, and thickness errors over steeply dipping seismic reflectors are to be expected. Similar problems have been discussed in several studies on salt-related structures (e.g. Marsh, Imber, Holdsworth, Brockbank, \& Ringrose, 2010). We ignored salt the salt overhangs when calculating salt thickness. By integrating the observations from cross-sectional stratal geometries with map-view variations in time-thickness, the relationship between salt-related structural activity and post-salt depocentre/minibasin evolution can be discerned. Moreover, for structural analysis, the position of the described structures is always based on present day locations, although their original locations may be far away from their current locations due to the movements that have occurred during thin-skinned extension and contraction (e.g. Marton et al., 2000; their fig. 9).

\section{PRESENT DAY STRUCTURAL STYLES}

The present-day structural style of the study area can be divided into two structural domains based on the tectono-stratigraphic style of the minibasins and salt-cored structural highs: i) elongate minibasins and salt walls in the east, and ii) elliptical minibasins and salt domes in the west (Figs 1a and 3). In both domains, the salt thickness varies significantly, from salt welds beneath minibasins, where its thickness is below seismic resolution, to over $2800 \mathrm{~ms}$ TWT along the core of salt walls. Many of the salt walls and diapirs form topographic highs on the seafloor (Fig. 1a).

The elongate minibasin-salt wall domain is characterized by NNE-SSW-striking minibasins that are $>60 \mathrm{~km}$ long and extend beyond the study area (Minibasins 1-4; Fig. 1a). The minibasins are separated by narrow, curvilinear salt walls of similar length (Salt Walls 1-4; Fig. 1a) (Fig. 3a). The minibasins are mostly welded to the sub-salt strata and are typically $12-20 \mathrm{~km}$ wide with sediment thickness between 2000 and 2800 ms TWT (Figs 3c, 4 and 5). The salt walls adjacent to the minibasins are typically $>2000 \mathrm{~ms}$ TWT higher than the base of minibasins and range in width from tens of metres, where the salt is vertically welded, to $2-5 \mathrm{~km}$ (Figs 3b, 4-7). Although these salt walls appear to be continuous on the seafloor (Fig. 1a), the salt thickness map indicates significant along-strike variability in thickness (Fig. 3b). For example, along Salt Wall 4, two salt 
diapirs and one salt dome are found separated by areas where the salt is vertically welded (Figs 3c and 4). Salt walls may also bifurcate, as seen in the northeastern part of Salt Wall 3 (Fig. 3a).

The elliptical minibasin-salt dome domain is characterized by minibasins that are typically elliptical in shape and the salt-cored structural highs range from diapirs and salt domes to short salt walls (Fig. 3a). The elliptical minibasins (Minibasins 5-7; Fig. 3b) are 10-18 km long and wide, with sediment thickness between 2000 and $2800 \mathrm{~ms}$ TWT. The salt domes and short salt walls (e.g. Salt Dome 1 and 2; Salt Wall 5 and 6; Fig. 3a) have varied planform geometries and typically range from 10 to $>20 \mathrm{~km}$ long, $5 \mathrm{~km}$ to $10 \mathrm{~km}$ wide (Fig. 3a). Salt thickness in salt domes is typically of the order of $1000 \mathrm{~ms}$ TWT, much lower than that in salt walls where thickness exceeds 2000 ms TWT (Fig. 3b).

\section{MIMIBASIN TECTONO-STRATIGRAPHY}

The supra-salt tectono-stratigraphy of the Lower Congo basin shows strong temporal and spatial variations both within and between individual minibasins.

\section{Albian}

The Albian succession thickens gradually from approximately $100 \mathrm{~ms}$ TWT in Minibasin 1, to 150-250 ms TWT in Minibasin 4 and the elliptical minibasin domain (Figs 4, 5 and 8a). Apparently thick Albian strata (>300 ms TWT) around salt-cored structural highs, including salt walls, domes and diapirs are artefacts due to steep dips around these structures (Figs 4 and $8 \mathrm{a}$ ). Subtle, sub-parallel NE-SW-striking lineations, 5-10 km long and 1 to $4 \mathrm{~km}$ apart, associated with can be seen in this succession throughout the study area (Fig. 8). The thinning of up to $50 \mathrm{~ms}$ TWT along these lineaments is thought to be due to fault cut-out along a network of normal faults active in the Cenomanian-Coniacian.

The absence of large-scale thickness variations and a lack of syn-tectonic growth strata within the carbonate-dominated Albian are in agreement with previous work in the area that interprets the Albian as pre-kinematic with limited salt tectonic activity (Fort et al., 2004; Valle et al., 2001).

\section{Cenomanian-Coniacian}

The thickness of the Cenomanian-Coniacian succession varies from $800 \mathrm{~ms}$ TWT in the east to 200-300 ms TWT in Minibasin 4 and further west (Fig. 8b). To the northeast of Minibasin 2 and 3, two major listric normal faults sole out northwestwards into the salt developing rollovers with a thickened succession, of $800 \mathrm{~ms}$ TWT thick, in their hanging walls (CC1 and CC2; Figs 4 and 
8b). A network of NE-SW-striking normal faults is developed across the study area with local thickest of sediment accumulated in small hanging wall depocentres (Figs 4 and 5). These normal faults correspond to the linear features observed in the Albian strata . Typically, the faults dip to the northwest, are 5-10 km long, have a spacing of 1 to $4 \mathrm{~km}$, and a maximum throw of $120 \mathrm{~ms}$ TWT (Fig. 8b). In cross-section, the faults rarely offset the top Coniacian (Figs 4 and 5).

The abundance of NE-SW-striking normal faults suggests that the study area underwent NWSE thin-skinned cover extension above the salt during the Cenomanian to Coniacian. The timing of extension corresponds to onset of the development of extensional raft tectonics further upslope, to the east of the study area (Duval et al., 1992; Marton et al., 2000; Valle et al., 2001) (Fig. 1b). The normal faulting in the study area ceased by end Coniacian times as none of the faults extend into the overlying strata (Figs $4 \mathrm{a}$ and $8 \mathrm{~b}$ ). This is much earlier than that in the upslope raft domain, where extension continued into the Miocene (Anderson et al., 2000).

\section{Santonian-Paleocene}

The Santonian-Paleocene succession shows significant local thickness variations (240-700 ms TWT) throughout the study area (Figs 4 and 8c). In the elongate minibasin domain, two depocentres (SP1 and 2; Fig. 8c), $3 \mathrm{~km}$ wide, $10 \mathrm{~km}$ long, and containing 250-300 ms TWT of Santonian-Paleocene strata, developed on the flanks of Minibasin 2, adjacent to Salt Wall 1 and 2 respectively (Fig. 8c). This depocentre geometry within represents a typical turtle structure where the succession thickens from middle to the flanks of the minibasin (Figs 4 and 5). In contrast, three 10-20 km long and up to $6 \mathrm{~km}$ wide depocentres (SP3, 4 and 5; Fig. 8c) lie centrally along the strike of Minibasin 3, and contain up to $360 \mathrm{~ms}$ TWT of strata that in cross-section are bowshaped and thin onto flanking salt walls (Fig. 8c). Depocentres in Minibasin 4 are similar in character. The depocentres in the elliptical minibasin domain have very different geometries. For example, Minibasin 5, in the southwest of the study area contains several depocentres that are up to $20 \mathrm{~km}$ long, 2-4 km wide, that have $300-600 \mathrm{~ms}$ TWT of strata within them (Fig. 8c). In crosssection, these depocentres contain growth strata associated with NE-SW-striking elongate folds and thrusts that have a wavelength of 2-4 km (Figs 6 and 7) and show evidence of inversion of pre-existing normal faults (Fig 6). In contrast, depocentre SP6 occurs broadly in the middle of Minibasin 7 with a thickness of over 650 ms TWT that thins towards flanking Salt Walls 4 and 6 (Fig. 4).

In this period, minibasin development in the elongate and the elliptical minibasin domains is variable. The formation of a turtle structure in Minibasin 2 in the elongate minibasin domain 
suggests that this minibasin became welded in the centre, halting further subsidence and shifting subsidence and sediment accumulation deposition towards its flanks (Fig. 5a). In contrast, the thick basin centre stratigraphy thinning towards the salt walls suggests salt was still being expelled into adjacent salt walls in Minibasin 3. The geometry of both minibasins indicates that the main control was sedimentary loading in the elongate minibasin domain during the Santonian to Paleocene (Hudec et al., 2009; Peel, 2014). The simultaneous observation of bow-shaped fills and and turtle structures in minibasins indicates different stages of minibasin maturity. Our observations also suggest that the present-day elongate minibasins initiated as a series of depocentres with limited connectivity during the Santonian which grew and linked subsequently (Figs 8c and 9). The linkage area generally occurred areas where remnant salt is trapped beneath the minibasin (Fig. 3b).

In the elliptical minibasin domain, the narrow, elongate folds and thrusts in the southwest of Minibasin 5 suggest that the area experienced thin-skinned contraction during the Santonian to Paleocene. The NE-SW-striking thrust faults and folds in this area are related to inversion of the NE-SW-striking Cenomanian-Coniacian normal faults and are interpreted to result from contraction that had migrated up-dip from the west (Figs 1b, 6 and 7). This interpretation of updip migration of the contraction domain is consistent with previous studies of the evolution of the contraction domain in the Lower Congo Basin (e.g. Fort et al., 2004).

\section{Eocene-Oligocene}

Most of the Eocene-Oligocene depocentres lie along the flanks of salt-cored structural highs (Fig. 8d). Depocentres in Minibasin 1-3 are between 700 and $900 \mathrm{~ms}$ TWT thick, 3-4 km wide, up to $28 \mathrm{~km}$ long, and run along both sides of the minibasins (Fig. 8d). In cross-section, these minibasins have the shape of a turtle structure, with relatively thin strata in the centre of the minibasins and thicker strata towards their flanks (Figs 4 and 5). In contrast, in Minibasin 4-7, the depocentres have ovoid planview geometries that are 5-8 km long and wide, and mainly occur flanking Salt Wall 4 (e.g. EO1 and EO2; Fig. 8d), and along the axis of Minibasin 4 (EO3; Fig. 8d). For example, in Minibasin 7, depocentre EO2 is thickest in the middle of the minibasin with $\geqslant 1000 \mathrm{~ms}$ TWT of growth strata that converge towards the Salt Dome 2 and Salt Wall 5 (Fig 7).

In the Eocene to Oligocene succession, the occurrence of turtle structures and the lack of extensional and contractional structures suggests that sediment loading was the dominant mechanism driving minibasin growth during this interval. Again, the minibasins show a range of structural styles that we interpret to reflect different stages of maturity. Turtle structures in 
Minibasin 1-3 suggest that the minibasins were mature and largely welded along the basin axes. In contrast, the depocentres in Minibasin 4-7 are located in the middle of the minibasins indicating that these minibasins still had mobile salt along their axes allowing continued subsidence and expulsion of salt into adjacent area salt-cored structures (Fig. 7). Specifically, bow-shaped depocentres developed in Minibasin 5 (Figs 5 and 7)which were affected by earlier contraction, suggesting a lack of tectonic activity in this period .

\section{Lower Miocene}

The Lower Miocene succession shows overall thickening from just over $100 \mathrm{~ms}$ TWT in the southeast, to more than $500 \mathrm{~ms}$ TWT thick in the northwest (Fig. 8e). In the elongate minibasin domain, the strata in each of Minibasins 1-3 thickens towards western flank from 50-150 to 300$350 \mathrm{~ms}$ TWT. In cross-sections, the depocentres are up to $6 \mathrm{~km}$ wide, $8-18 \mathrm{~km}$ long, and slightly thicken in the west and thin towards the flanking salt walls (Figs 4-7). In Minibasin 4, a $15 \mathrm{~km}$ long and $8 \mathrm{~km}$ wide depocentre, LM1, with over $350 \mathrm{~ms}$ TWT of Lower Miocene strata occurs along the eastern flank of the minibasin, and a nearby depocentre, LM2, is located along the northwestern flank of the minibasin (Figs 6 and 8e). Depocentres in the elliptical minibasin domain contain over $500 \mathrm{~ms}$ TWT of strata and thin onto flanking salt-cored structural highs (Fig. 8e). No folding or near diapir pinch-out has been observed (Figs 4-7).

The Lower Miocene succession is interpreted to be controlled by a combination of regional tilting and sedimentation. A plausible explanation for the asymmetrical stratal thickening towards the flanking salt-cored structures is regional contraction. However, such interpretation is in contradiction with the collapsed graben observed between Salt Dome 2 and Salt Wall 5. Moreover, a previous study has also suggested thin-skinned contraction only started in the Late Miocene (Valle et al., 2001). We therefore interpret the preferential distribution of depocentres in Minibasins 1-3 in the west as a result of northwest tilting of the margin associated with the uplift of the African continent (Anka \& Séranne, 2004; Lavier et al., 2001). Tilting caused the northwestern parts of the minibasins to become topographic lows focusing sediment transport and accumulation in those areas. Sediment loading still is an important control in the elliptical minibasin domain, with continued salt withdrawal and depocentre subsidence surrounding Salt Dome 2 and the southern end of Salt Wall 4.

\section{Upper Miocene}

The Upper Miocene has very variable sediment thicknesses both between and within minibasins. 
For example, depocentres in the Minibasin 3 and 4 are up to $50 \mathrm{~km}$ long and $15 \mathrm{~km}$ wide with local thickness $>600 \mathrm{~ms}$ TWT (Fig. 8f). These thick accumulations contrast with minibasins 2, 6 and 7 where the strata are ca. $200 \mathrm{~ms}$ TWT thick (Fig. 8f). In contrast to the Lower Miocene, where depocentres usually lie on the flanks of salt-cored structural highs, the depocentres in the Upper Miocene are located along the centre of the minibasins (Fig. 8f). In cross-section, the Upper Miocene strata always thin towards the salt structures forming bow-shaped growth wedges (Figs 4 and 5).

The Miocene as a whole is a period of relatively high sediment supply and there is ample evidence that deposition occurred in system of turbidite channels, lobes and fans (Oluboyo et al., 2014). Some of the thickness variations between minibasins observed particularly in the Upper Miocene are due to the sediment routing being fixed to particular minibasins while others are relatively starved (e.g. Minibasin 2). During the Upper Miocene, thinning of strata towards the salt-cored structural highs suggests that sediment accumulation occurred along the basin centre due to the rise of salt-cored structures. The growth strata and the associated variable thickness distribution also indicate that the salt-cored highs are sufficient to confine the sedimentary systems laterally. The growth and elevation of salt-cored highs (i.e. diapirs and salt walls) are interpreted to result from thin-skinned contraction that squeezed the weak salt-cored structures (Callot et al., 2012; Rowan \& Vendeville, 2006). This contraction affects the entire study area. Regionally, this contraction coincides with continuing upslope extension to the east of the study area (Valle et al., 2001)

\section{Pliocene-Holocene}

The Pliocene-Holocene succession shows gradual thinning from approximately $700 \mathrm{~ms}$ TWT in Minibasin 1 and 2 to just over $300 \mathrm{~ms}$ TWT in the elliptical minibasin domain (Fig. 8g). Overall, the depocentres form elongate wedges along the centre of the minibasins that thin onto the flanking salt-cored highs (Fig. 4). Many of the growth wedges are asymmetrical with the thickest strata along their eastern sides, for example, Minibasins 3 and 4 (Fig. 4). These asymmetrical growth wedges are associated with thrusts and vertical salt welds where the eastern limb of the salt wall is welded and/or thrust over its western limb, for example, Minibasin 3 (Fig. 5).

The Pliocene-Holocene succession is similar to the Upper Miocene where the sedimentary growth strata accumulated as the salt-cored structural highs rose (Fig. 4). However, the access to sediment supply has been restored as the Minibasin 2 has thickest strata (Fig. 8g). More importantly, contrasting to the Upper Miocene depocentres developed along the axis of the 
minibasins, the growth wedges of Pliocene-Holocene are locally asymmetrical due to thrusting over salt walls under continuous contraction (Fig. 5). Nevertheless, the contraction in the PlioceneHolocene is a continuation from Upper Miocene times.

\section{DISCUSSION}

Mapping of key stratigraphic surfaces and analysis of time-thickness maps shows the location and geometry of minibasins and flanking salt-cored highs have considerable spatial variability across the study area through time. We propose that such variability is controlled by a number of interacting mechanisms that vary in space and time. In this section, we discuss the $3 \mathrm{D}$ development of the minibasins, the spatial and temporal variability of minibasin geometry and how these are influenced by minibasin maturity as well as the impact of kinematic domain migration on minibasin evolution.

\section{D development of minibasins}

Previous studies of passive margin salt basins, including physical and numerical modelling studies have generally considered minibasin development in conjunction with salt-related structures along the dip-orientated transects from basin margin to the toe of slope (Brun \& Fort, 2012; Duval et al., 1992; Ings \& Beaumont, 2010; Mauduit et al., 1997; Peel, 2014; Rowan et al., 2004). For example, in a benchmark paper on minibasin formation, Hudec et al. (2009) summarize the geometric and stratigraphic character of minibasins under sedimentary loading, contraction and extension in 2D. Minibasins driven by sediment loading typically have a central topographic low, with relatively thick syn-tectonic strata, that thin onto the surrounding salt-cored highs (Fig. 4) (e.g. Hudec et al., 2009; Peel, 2014). Extension creates extensional diapirs as well as rollovers and normal faults in the supra-salt cover (e.g. Fig. 4) (e.g. Gemmer et al., 2005; Mauduit et al., 1997). In contrast, contraction may form folds and thrusts as well as the salt-cored structural highs (Figs 5 and 9e) (Brun \& Fort, 2004; Hudec et al., 2009).

Our analysis of 3D seismic data from the Angola margin also shows strong along-strike variability in minibasin development. The present-day configuration of elongate minibasins started off from a pervasive network of small normal faults and (2-4 km long and 1-4 km spacing (Fig. 9a))a few large rollovers (e.g. CC1 and CC2 in Fig. 8b). Later, a number of distinct depocentres occurred (up to $20 \mathrm{~km}$ long) which subsequently grew and merged into single minibasins of over $50 \mathrm{~km}$. For example, during the Santonian to Paleocene, three isolated, depocentres (SE3-5) 
occurred along strike in Minibasin 3 before merged into a single minibasin during the Eocene to Paleocene (Figs 9b and c). From the Miocene onwards minibasins show less along-strike variability (Fig. 9d and e) as regional tilting and subsequent thin-skinned contract took control,. Although an explicit, more detailed analysis of the along-strike evolution of minibasin is beyond the scope of this study, our results suggest a simple 2D transect is inadequate to capture the alongstrike growth and heterogeneity in large, elongate minibasins.

\section{Variability of controlling mechanism and minibasin maturity on minibasin evolution}

The growth of minibasins on passive margins is interpreted to result from a range of different driving mechanisms (e.g. Brun \& Fort, 2011; Hudec et al., 2009; Peel, 2014). Minibasins may start with extension, sedimentary loading (downbuilding) and contraction as they initiate in different kinematic domains during thin-skinned deformation, and extensional and sediment-dominated minibasins can be superimposed by contraction due to upslope migration of the contractional domain (Fig. 9) (Fort et al., 2004; Hudec et al., 2009; Peel, 2014). As mentioned in the previous section, each of these driving mechanisms generates a characteristic topography and minibasin geometry (Fig. 9) (Hudec et al., 2009). Therefore, changes of driving mechanisms during minibasin formation and evolution can result in marked variability in minibasin geometry and growth strata architecture.

In this study, in addition to lateral growth of minibasin development, we highlight the variability in minibasin geometry during their evolution. As a minibasin matures, eventually welds onto the sub-salt strata. In addition, because minibasins develop at different rates,minibasins at different stages of maturity can co-exist (Fig. 10). In minibasins dominated by sediment loading (downbuilding) (Fig. 10a), the underlying salt eventually depletes and the supra-salt strata weld onto the sub-salt strata below. During the welding process, the depositional topography of the minibasin may change from having a central depocentre 'low' to a turtle structure where the depocentres migrate to the flanks of the minibasin (Fig. 10a). An example of typical minibasin downbuilding geometry with a central low can be seen in the Santonian to Paleocene strata in Minibasin 3, while only a few kilometres away to the east across Salt Wall 2, Minibasin 2 has already developed a central turtle structure (Figs 4 and 8c). Moreover, such variability in maturity not only occurs between minibasins but also exists within individual minibasins. For example, during along-strike and linkage, Minibasin 2 shows considerable along-strike variation of growth rate during depocentre growth and linkage from Santonian to Paleocene (Fig. 8c). Furthermore, as 
minibasins with different maturity have variable minibasin geometry, their response to changes of minibasin controls also vary. In the southwestern part of the study area, contraction occurred during the Santonian when the extensional minibasins were in their early stages of development, which resulted in small wavelength and elongate folds and thrusts due to the relatively thin cover strata (Fig. 7). In contrast, contraction during the Late Miocene, when the minibasins were more matured and welded, resulted in squeezed salt walls and diapirs in the study area (Fig. 10b).

Based on the literature and examples gathered from this study, we recognize six typical minibasin geometries that associated with minibasin maturity during thin skinned-deformation. Typically, gravity driven thin-skinned salt tectonics have kinematic domains of extension, translation and contraction (Fort et al., 2004; Rowan et al., 2004). Correspondingly, main minibasin controls of extension, sediment loading and contraction, are generally associated with these three kinematic domains (Fig. 10a). In the extensional domain, minibasins occur with extensional diapirs and normal faults followed by welding on the sub-salt with extension accommodationed by diapirs (cryptic extension,) (Fig. 10a.i). In the translation domain, sediment loading forms early symmetrical minibasins which later turn into minibasins with turtle structures (Fig. 10a.ii). In the contraction domain, early contraction results in short wavelength folds and thrusts, which later develop into minibasins bounded by squeezed diapirs (Fig. 10a.iii). Moreover, as the main control changes during upslope migration of contraction, four more minibasin geometries are recognized (Fig. 10b). When the contractional domain migrates to the translational domain, early stage minibasins dominated by sediment loading become asymmetrical as the depocentre shifts away from the basin centre (Fig. 10b.iv). In contrast, when contraction occurs onto a minibasin with a mature turtle structure the adjacent salt diapirs are uplifted while confining and narrowing the depocentre (Fig. 10b.iv). When contraction migrates to the extensional domain, early stage extensional minibasins tend to form folds and thrusts (Fig. 10.v). In contrast, when contraction occurs onto matured and welded extensional minibasins, the resultant minibasins tend to have a simple geometry with narrower depocentres confined by the uplifted, adjacent salt diapirs (Fig. 10b.vi).

\section{CONCLUSIONS}

A regionally consistent interpretation of 3D seismic data from the Lower Congo Basin, calibrated with well data, enables analysis of the tectono-stratigraphic evolution of the supra-salt strata and assessment of tectonic and sedimentary controls on minibasins and associated salt diapirs/walls evolution. The supra-salt cover in the study area is dominated by NE-SW-striking minibasins 
separated by salt walls.

Time-thickness maps show that the salt and post-salt stratal thicknesses change rapidly across the study area. The present-day minibasin and salt wall configurations are the result of three main controls: thin-skinned extension, sediment loading and thin-skinned contraction. After a short initial period of tectonic quiescence, thin-skinned extension started from the Cenomanian to Coniacian and was characterized by a pervasive network of normal faults and rollovers. Subsequent minibasin and salt wall evolution was dominated by sediment loading and minibasin downbuilding, with a brief period of contraction affecting the southwest of the study area. Regional thin-skinned contraction occurred in the Miocene across the entire study area and resulted in squeezed salt walls and confined depocentres.

We show minibasins developed from multiple depocentres along strike in the early stages that grow and merge over time. Moreover, as minibasins grow at different rates, variability of minibasin geometry associated with different stages of minibasin maturity exist between minibasins as well as within individual minibasins. The upslope migration of contraction adds another layer of variability of minibasin geometry, because immature and mature minibasins respond to thinskinned contraction differently.

As minibasins occur in different kinematic domains, their geometry and stratigraphic architecture show considerable variation. Minibasins in the translational domain controlled by sediment loading tend to develop symmetrical geometries as they subside into the underlying salt and form turtle structure as they become welded. In contrast, minibasins in extensional and contractional domains have diagnostic extensional and contractional structures such as normal faults and folds and thrusts. As contraction migrates upslope during thin-skinned salt deformation, sediment loading dominated minibasins are superimposed by contraction and develop squeezed salt diapirs with shifted or narrower depocentres. In contrast, extensionally driven minibasins tend to get inverted by contraction, developing folds and thrusts as well as narrower depocentres.

This study shows that the 3D geometry, topography, stratigraphic architecture and evolution of minibasins are variable and complex due to along-strike evolution, variations of minibasin maturity and upslope migration of contraction. This variability of minibasin evolution contrasts to existing models which generally associate one minibasin with only one main control, namely extension, sediment loading or contraction depending on whether it formed in the extensional, translational or contractional during thin-skinned salt tectonic evolution.

\section{ACKNOWLEDGEMENTS}


We thank Equinor AS for sponsoring the Turbidites, Topography and Tectonics (T3) project and providing proprietary well data. We acknowledge PGS for providing access to seismic data and giving permission to publish the seismic sections in this paper. Schlumberger is thanked for providing Petrel software in the 3D Seismic Lab in the University of Bergen. Atle Rotevatn is thanked for discussion during early stage of this study.

\section{REFERENCES}

Anderson, J. E., Cartwright, J., Drysdall, S. J., \& Vivian, N. (2000). Controls on turbidite sand deposition during gravity-driven extension of a passive margin: examples from Miocene sediments in Block 4, Angola. Marine and Petroleum Geology, 17(10), 1165-1203.

Anka, Z., \& Séranne, M. (2004). Reconnaissance study of the ancient Zaire (Congo) deep-sea fan.(ZaiAngo Project). Marine Geology, 209(1), 223-244.

Anka, Z., Seranne, M., Lopez, M., Scheck-Wenderoth, M., \& Savoye, B. (2009). The long-term evolution of the Congo deep-sea fan: A basin-wide view of the interaction between a giant submarine fan and a mature passive margin (ZaiAngo project). Tectonophysics, 470(1), 42-56.

Banham, S. G., \& Mountney, N. P. (2013). Evolution of fluvial systems in salt-walled mini-basins: a review and new insights. Sedimentary Geology, 296, 142-166.

Brice, S. E., Cochran, M. D., Pardo, G., \& Edwards, A. D. (1982). Tectonics and Sedimentation of the South Atlantic Rift Sequence: Cabinda, Angola: Rifted Margins: Field Investigations of Margin Structure and Stratigraphy.

Brun, J.-P., \& Fort, X. (2004). Compressional salt tectonics (Angolan margin). Tectonophysics, 382(3), $129-150$.

Brun, J.-P., \& Fort, X. (2011). Salt tectonics at passive margins: Geology versus models. Marine and Petroleum Geology, 28(6), 1123-1145.

Brun, J.-P., \& Fort, X. (2012). Salt tectonics at passive margins: geology versus models-Reply. Marine and Petroleum Geology, 37(1), 195-208.

Callot, J.-P., Trocmé, V., Letouzey, J., Albouy, E., Jahani, S., \& Sherkati, S. (2012). Pre-existing salt structures and the folding of the Zagros Mountains. Geological Society, London, Special Publications, 363(1), 545-561.

Cramez, C., \& Jackson, M. P. A. (2000). Superposed deformation straddling the continental-oceanic transition in deep-water Angola. Marine and Petroleum Geology, 17(10), 1095-1109.

Duval, B., Cramez, C., \& Jackson, M. P. A. (1992). Raft tectonics in the Kwanza basin, Angola. Marine and Petroleum Geology, 9(4), 389-404.

Fort, X., Brun, J.-P., \& Chauvel, F. (2004). Salt tectonics on the Angolan margin, synsedimentary deformation processes. AAPG Bulletin, 88(11), 1523-1544.

Gemmer, L., Beaumont, C., \& Ings, S. J. (2005). Dynamic modelling of passive margin salt tectonics: effects of water loading, sediment properties and sedimentation patterns. Basin Research, 17(3), 383-402.

Goteti, R., Ings, S. J., \& Beaumont, C. (2012). Development of salt minibasins initiated by sedimentary topographic relief. Earth and Planetary Science Letters, 339-340, 103-116. doi:http://dx.doi.org/10.1016/j.epsl.2012.04.045

Hodgson, N. A., Farnsworth, J., \& Fraser, A. J. (1992). Salt-related tectonics, sedimentation and hydrocarbon plays in the Central Graben, North Sea, UKCS. Geological Society, London, Special Publications, 67(1), 31-63.

Hudec, M. R., \& Jackson, M. P. A. (2007). Terra infirma: Understanding salt tectonics. Earth-Science Reviews, 82(1), 1-28. 
Hudec, M. R., Jackson, M. P. A., \& Schultz-Ela, D. D. (2009). The paradox of minibasin subsidence into salt: Clues to the evolution of crustal basins. Geological Society of America Bulletin, 121(1-2), 201-221.

Ings, S. J., \& Beaumont, C. (2010). Shortening viscous pressure ridges, a solution to the enigma of initiating salt 'withdrawal'minibasins. Geology, 38(4), 339-342.

Jackson, M. P. A., \& Talbot, C. J. (1991). A glossary of salt tectonics: Bureau of Economic Geology, University of Texas at Austin.

Jackson, M. P. A., Vendeville, B. C., \& Schultz-Ela, D. D. (1994). Structural dynamics of salt systems. Annual Review of Earth and Planetary Sciences, 22, 93-117.

Karner, G. D., Driscoll, N. W., McGinnis, J. P., Brumbaugh, W. D., \& Cameron, N. R. (1997). Tectonic significance of syn-rift sediment packages across the Gabon-Cabinda continental margin. Marine and Petroleum Geology, 14(7-8), 973-1000.

Lavier, L. L., Steckler, M. S., \& Brigaud, F. (2001). Climatic and tectonic control on the Cenozoic evolution of the West African margin. Marine Geology, 178(1), 63-80.

Lundin, E. R. (1992). Thin-skinned extensional tectonics on a salt detachment, northern Kwanza Basin, Angola. Marine and Petroleum Geology, 9(4), 405-411.

Marsh, N., Imber, J., Holdsworth, R. E., Brockbank, P., \& Ringrose, P. (2010). The structural evolution of the Halten Terrace, offshore Mid - Norway: extensional fault growth and strain localisation in a multi - layer brittle - ductile system. Basin Research, 22(2), 195 - 214.

Marton, G., Tari, G. C., \& Lehmann, C. T. (2000). Evolution of the Angolan Passive Margin, West Africa, With Emphasis on Post - Salt Structural Styles. Geophysical Monograph-American Geophysical Union(115), 129-149.

Mauduit, T., Gaullier, V., Brun, J., \& Guerin, G. (1997). On the asymmetry of turtle-back growth anticlines. Marine and Petroleum Geology, 14(7), 763-771.

Moulin, M., Aslanian, D., Olivet, J.-L., Contrucci, I., Matias, L., Géli, L., . . Unternehr, P. (2005). Geological constraints on the evolution of the Angolan margin based on reflection and refraction seismic data (ZaïAngo project). Geophysical Journal International, 162(3), 793-810.

Nürnberg, D., \& Müller, R. D. (1991). The tectonic evolution of the South Atlantic from Late Jurassic to present. Tectonophysics, 191(1), 27-53.

Oluboyo, A. P., Gawthorpe, R. L., Bakke, K., \& Hadler - Jacobsen, F. (2014). Salt tectonic controls on deep - water turbidite depositional systems: Miocene, southwestern Lower Congo Basin, offshore Angola. Basin Research, 26(4), 597 - 620.

Peel, F. J. (2014). How do salt withdrawal minibasins form? Insights from forward modelling, and implications for hydrocarbon migration. Tectonophysics, 630, 222-235.

Rowan, M. G., Peel, F. J., \& Vendeville, B. C. (2004). Gravity-driven fold belts on passive margins. In K. R. McClay (Ed.), AAPG Memoir (Vol. 82, pp. 157-182).

Rowan, M. G., \& Vendeville, B. C. (2006). Foldbelts with early salt withdrawal and diapirism: Physical model and examples from the northern Gulf of Mexico and the Flinders Ranges, Australia. Marine and Petroleum Geology, 23(9), 871-891.

Valle, P. J., Gjelberg, J. G., \& Helland-Hansen, W. (2001). Tectonostratigraphic development in the eastern Lower Congo Basin, offshore Angola, west Africa. Marine and Petroleum Geology, 18(8), 909-927.

Vendeville, B. C., \& Jackson, M. P. A. (1992). The rise of diapirs during thin-skinned extension. Marine and Petroleum Geology, 9(4), 331-354. 


\section{FIGURE CAPTIONS}
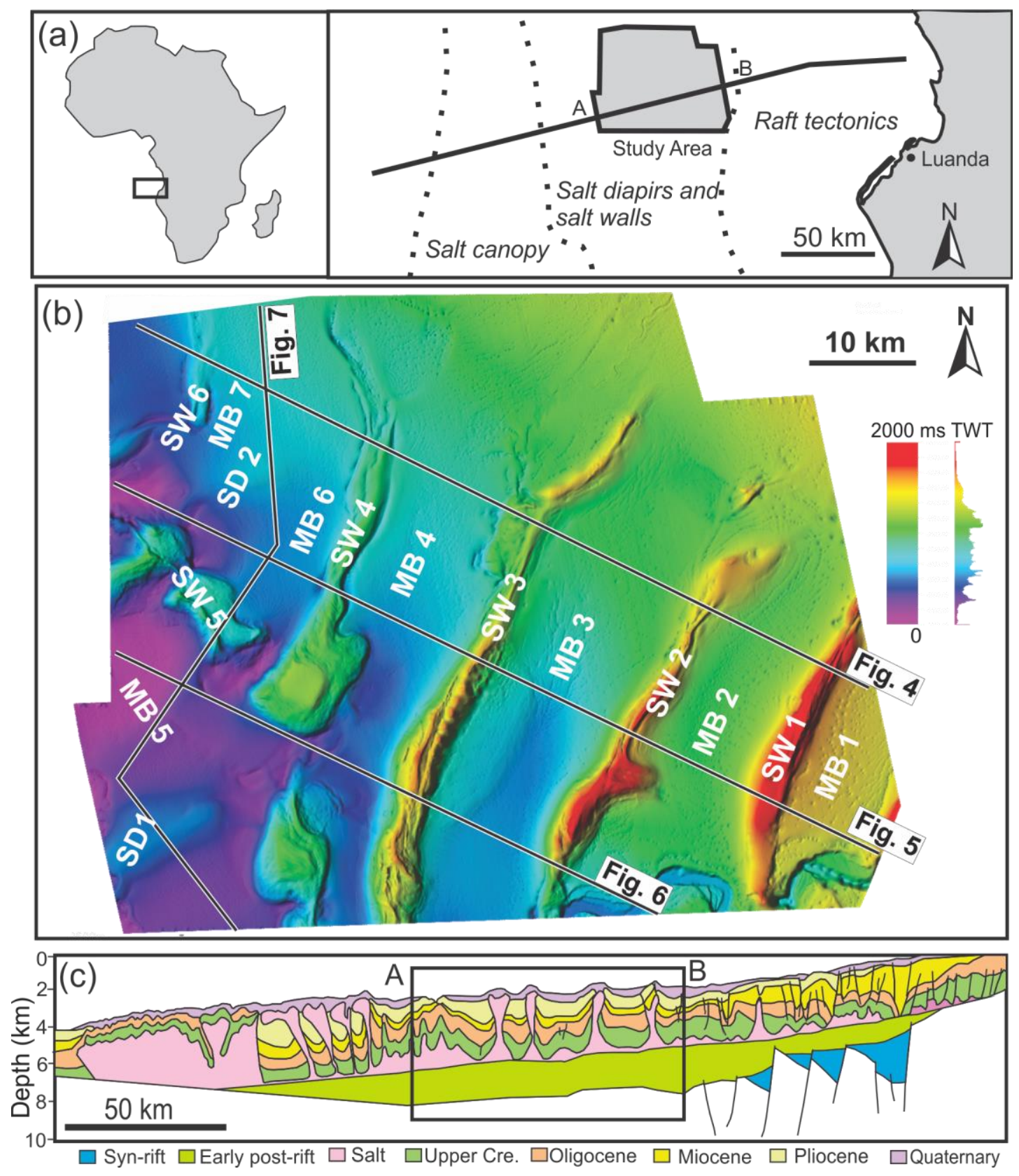

Fig 1. (a) The geological location of the datasect and study area in the context of Africa. (b)

Two-way travel time structure map of the seafloor illustrating the main structural elements in the study area. $\mathrm{MB}=$ minibasin; $\mathrm{SW}=$ salt wall; $\mathrm{SD}=$ salt dome. See (a) for location. (c) Regional seismic profile crossing the Lower Congo Basin (modified after Martonet al., 2000), showing the $200 \mathrm{~km}$ long, thin-skinned gravity-driven system developed above the salt. Approximate location of the study area on this regional profile is indicated by AB. The location of the profile is shown in (a). 


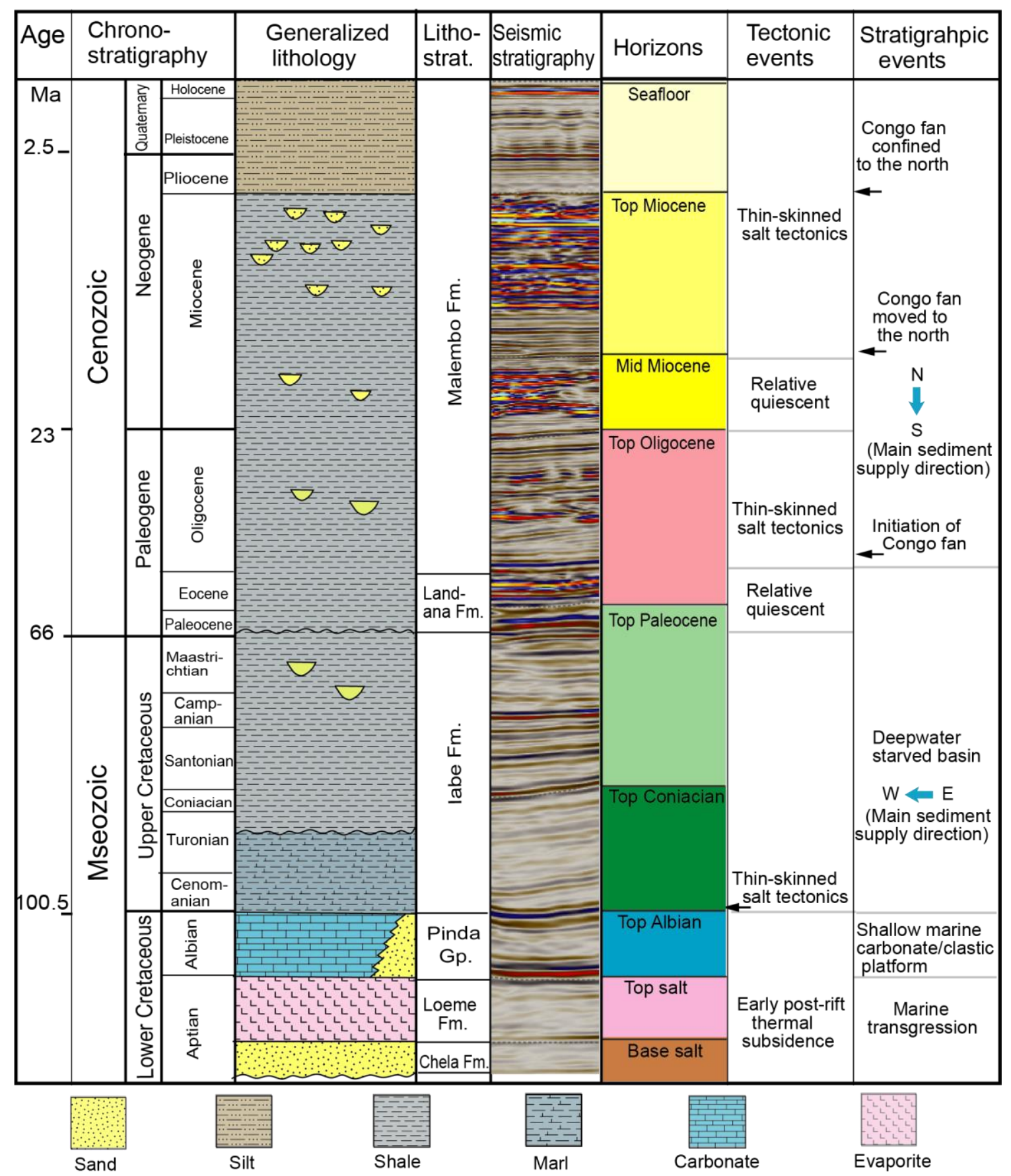

Fig. 2. Stratigraphy and interpreted horizons of the Lower Congo Basin (modified after Anderson et al., 2000; Valle et al., 2001; Anka \& Séranne, 2004). 

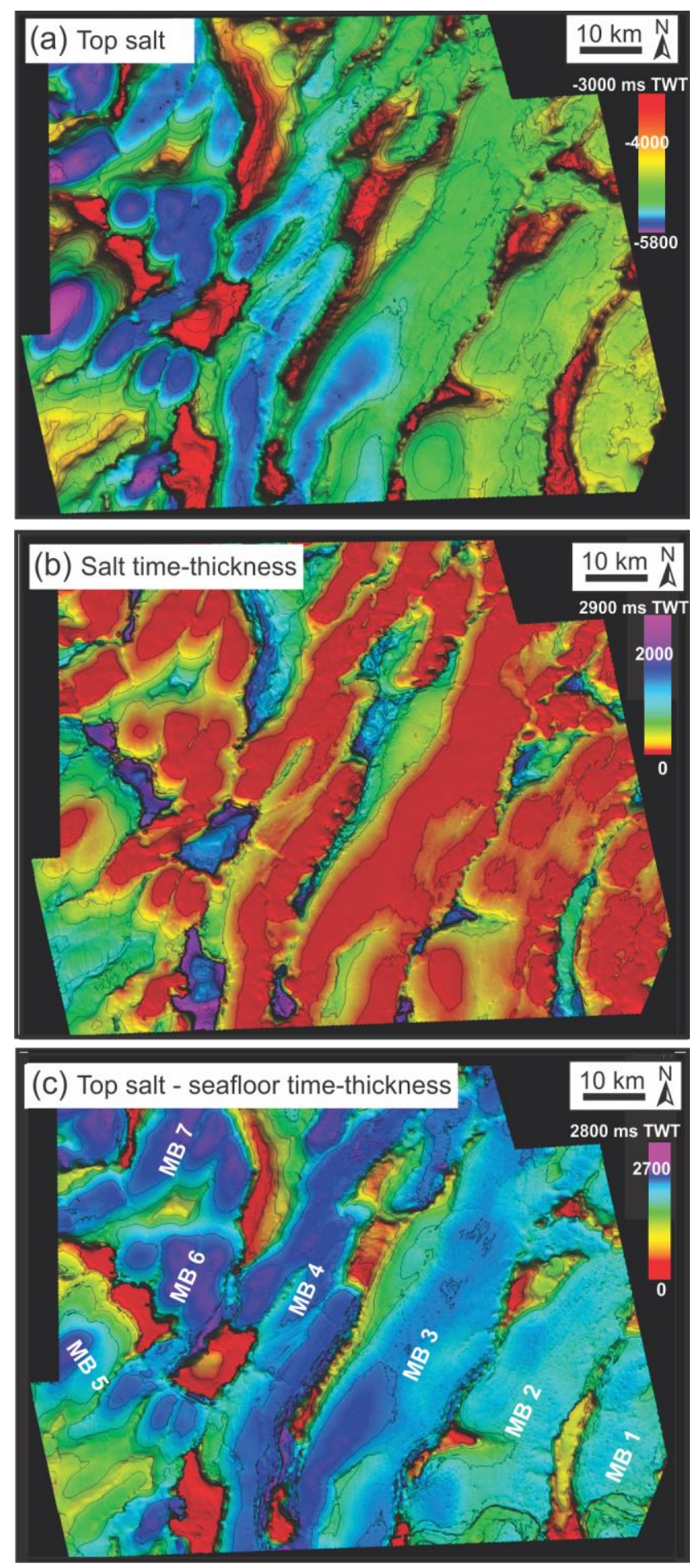

Fig. 3. Key overview maps of the study area. (a) TWT structure map of the top salt horizon illustrating locations and geometries of the minibasins and salt walls/diapirs, the overall regional slope in the base of post-salt stratigraphy as indicated. (b) Two-way time thickness of the salt showing the location of salt welds (thin) and salt walls/diapirs (thick). (c) Two-way time thickness from top salt to seafloor showing post-salt deposits thickening towards the centre of the minibasins and thinning on to the salt highs. 


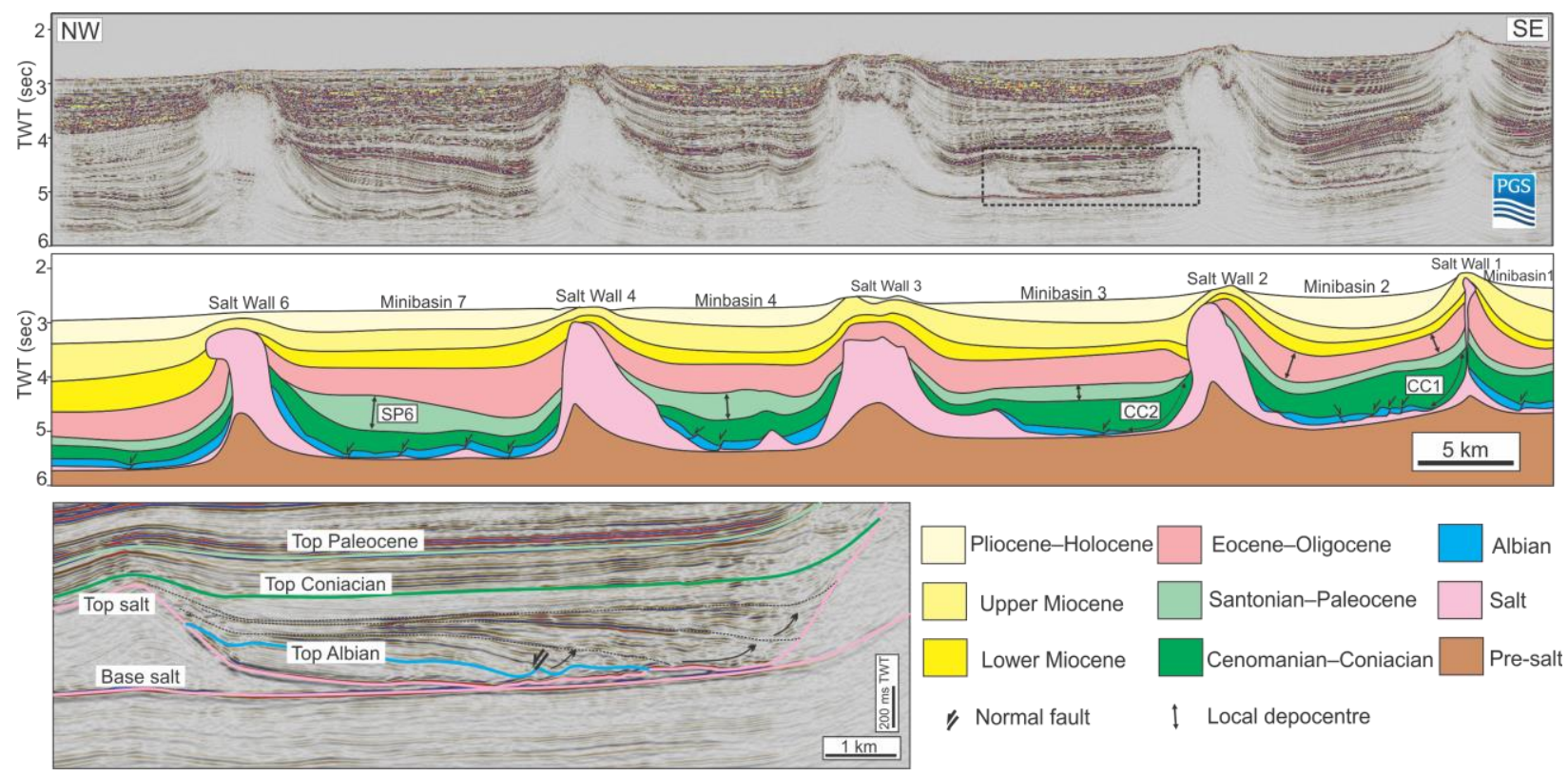

Fig 4. Seismic section (above) and interpretation (below) illustrating the structural style of minibasins and salt walls/diapirs in the northeast of the study area. Note the two large rollovers of $\mathrm{CC} 1$ and $\mathrm{CC} 2$ from Cenomanian to Coniacian and severe velocity pull-ups in the pre-salt strata. The inset shows details of the rollover CC2. CC1, CC2 and SP6 are described in the text. For section location, see Fig. 3 or 8. For legend, see Fig. 2. 

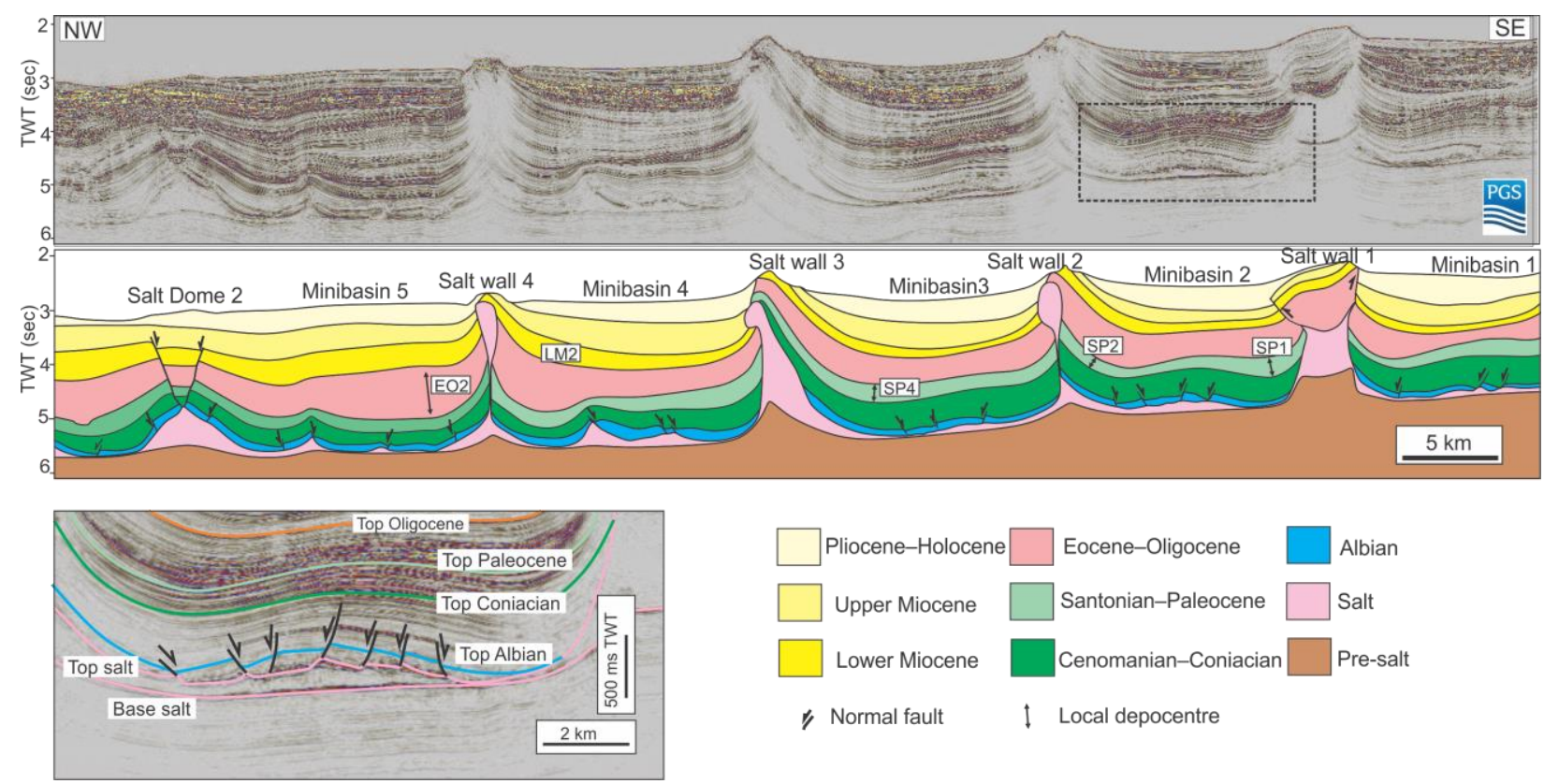

Fig 5. Seismic section (above) and interpretation (below) illustrating the structural style of minibasins and salt walls/diapirs in the middle of the study area. The inset shows the style of Cenomanian to Coniacian normal faults. SP1, SP2, SP4, EO1 and LM2 are described in the text. For section location, see Fig. 3 or 8. For legend, see Fig. 2. 

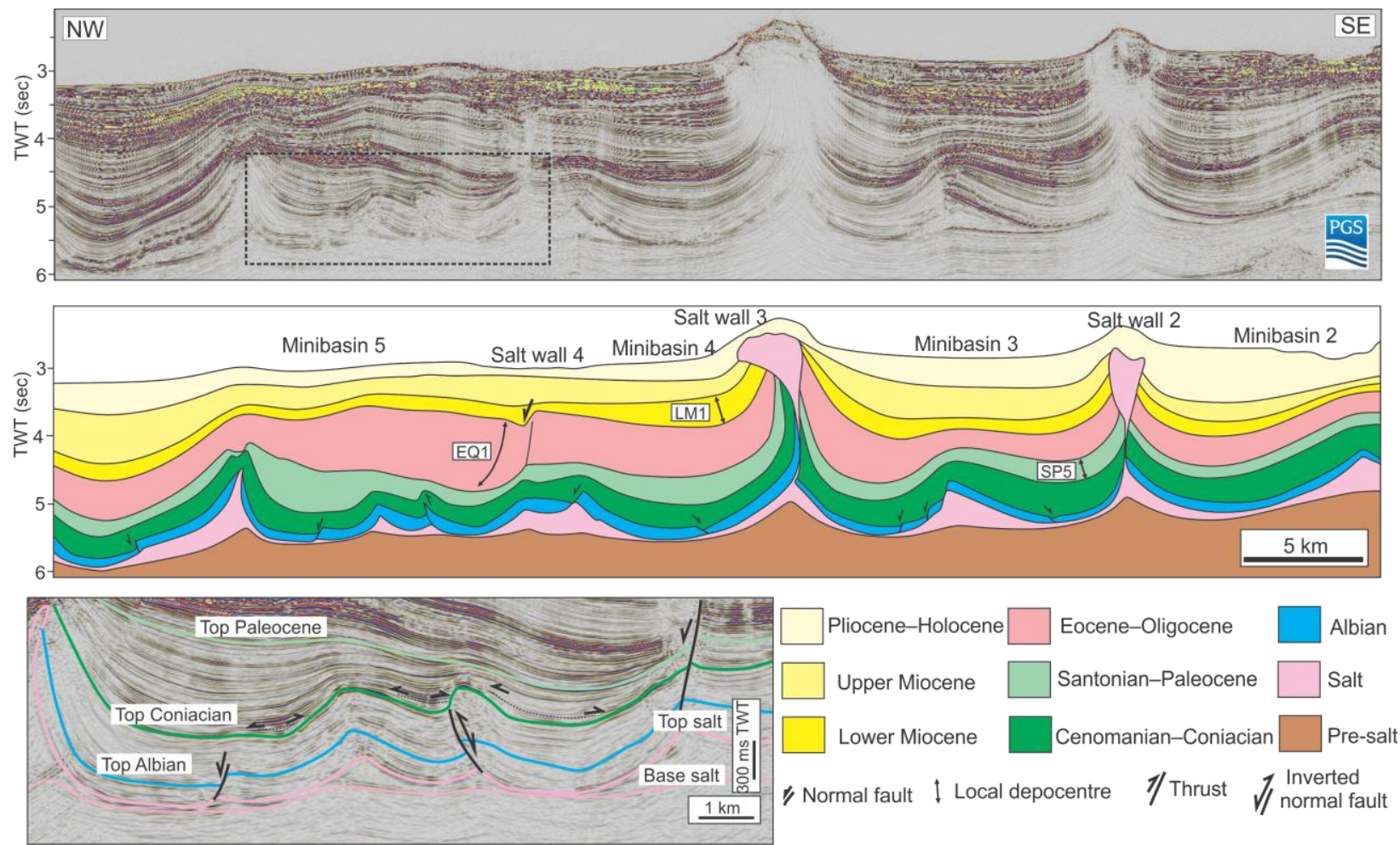

Fig 6. Seismic section (above) and interpretation (below) illustrating the structural style of minibasins and salt walls/diapirs in the south of the study area. Note the thrusts and folds from Santonian to Paleocene. The inset shows details of the thrust and fold geometry. Note the inverted normal fault. SP5, EQ1 and LM1 are described in the text. For section location, see Fig. 3 or 8. For legend, see Fig. 2. 

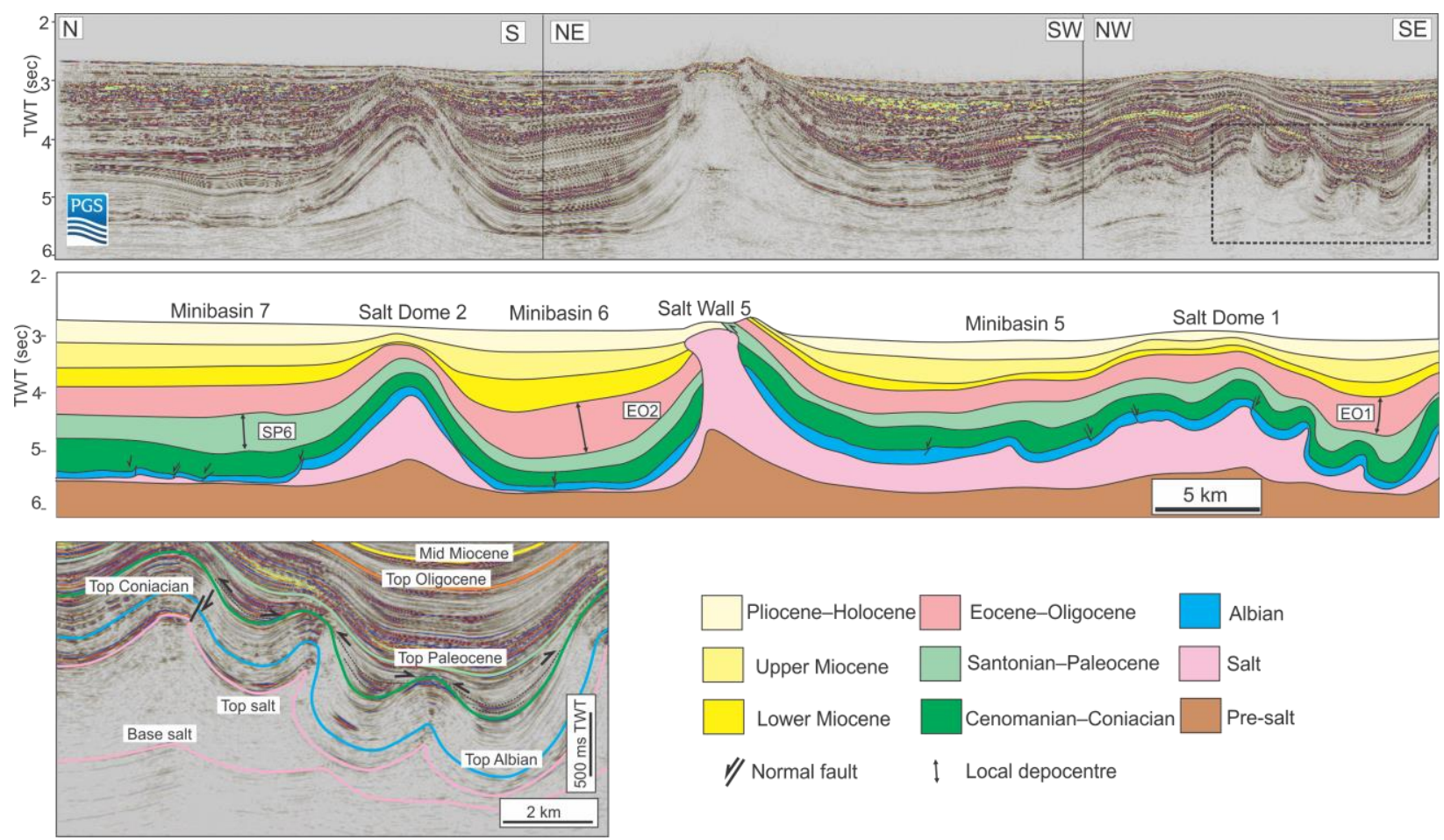

Fig 7. Seismic section (above) and interpretation (below) illustrating the structural style of minibasins and salt domes and diapirs in the west of the study area. The inset shows the details of the folds developed from Santonian to Paleocene. EO1, EO2 and SP6 are described in the text. For section location, see Fig. 3 or 8. For legend, see Fig. 2. 

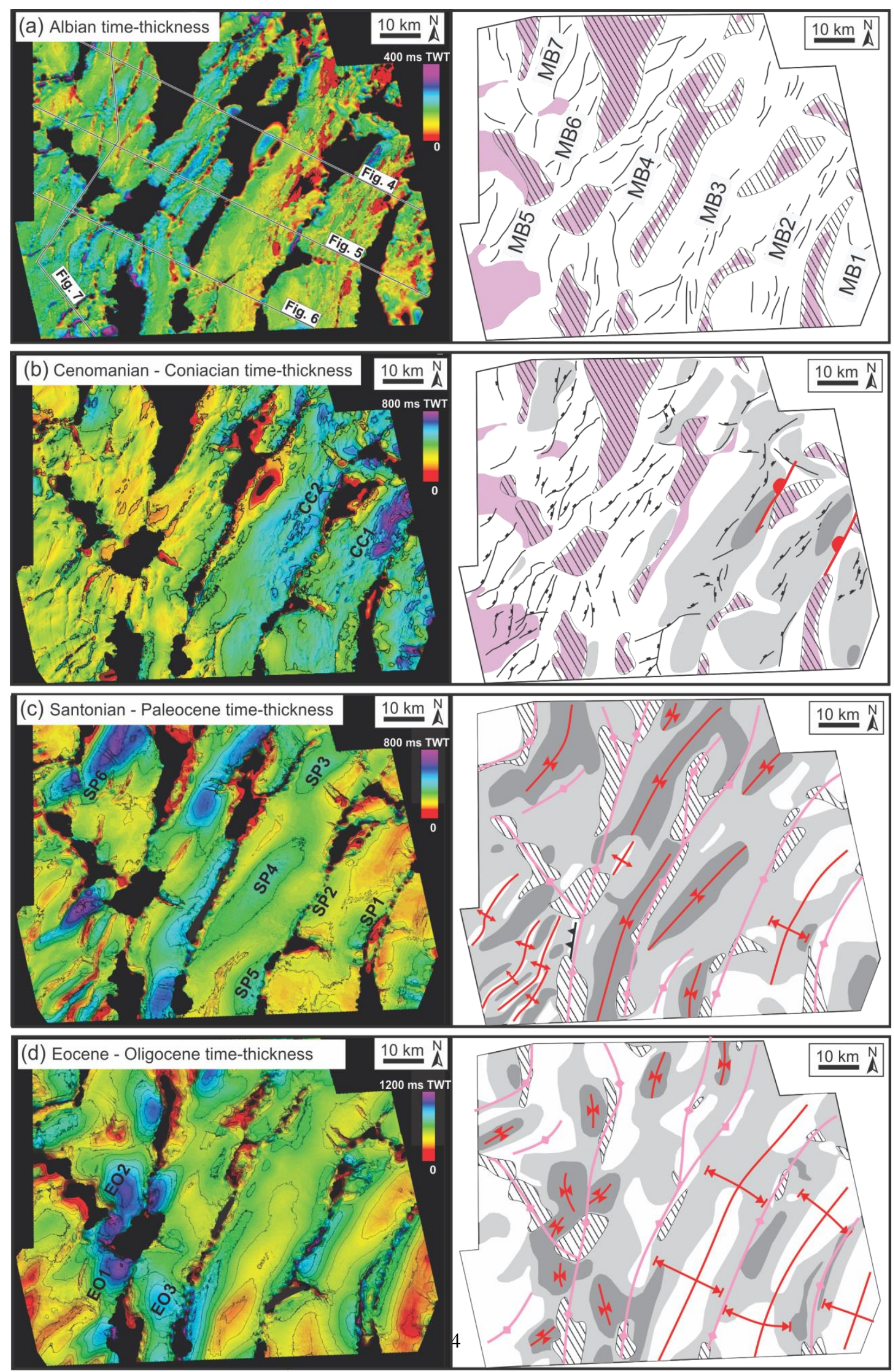

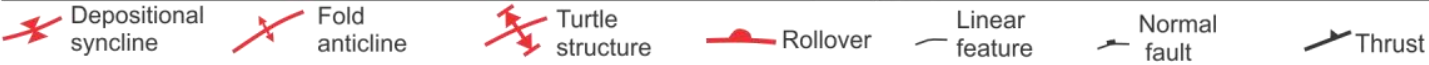

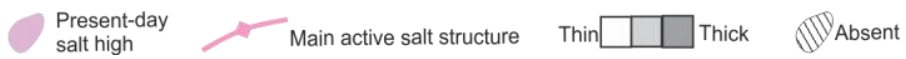


Fig 8. Two-way time thickness maps for each of the seven supra-salt stratigraphic intervals. Each of these maps is accompanied by a sketch illustrating the key structural/topographic features on the right. (a) Albian time-thickness map, linear features indicate subtle thickness variations due to cutouts along faults that occurred later. (b) Cenomanian-Coniacian time-thickness map with widespread normal faults and the location of two rollover structures $\mathrm{CC} 1$ and $\mathrm{CC} 2$ observed in the east of MB2 and MB3. Note that this package thins from SE to NW. (c) Santonian-Paleocene time-thickness map illustrates depocentre distribution and fold and thrust structures. Depocentres SP1-6 are marked on the thickness map. (d) Eocene-Oligocene time-thickness map displays the development of turtle structures in the elongate minibasin domain and distributed depocentres in the elliptical minibasin domain. Depocentres EO1 and EO2 are marked on the thickness map. 

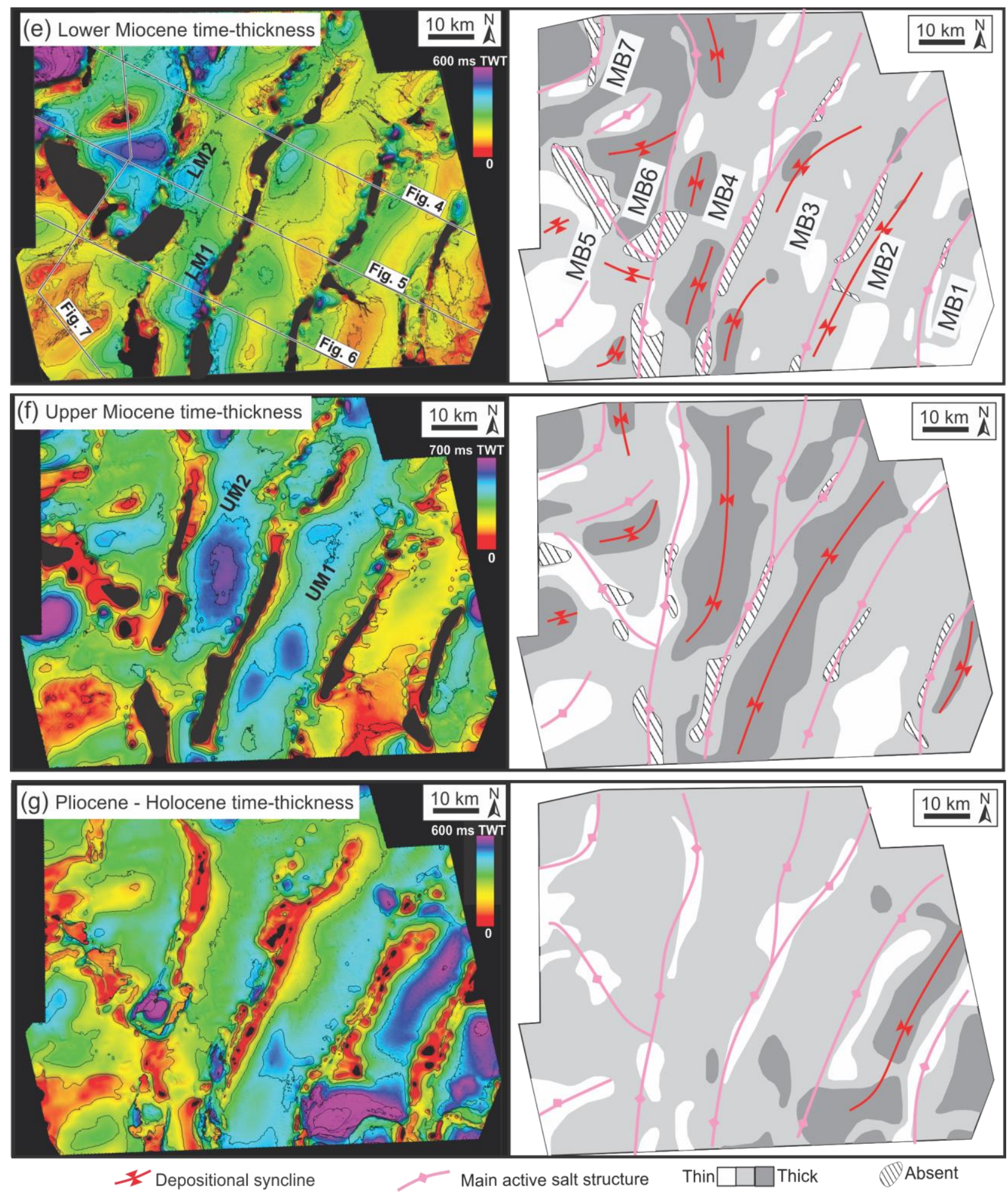

Fig 8 (continued). (e) Lower Miocene time-thickness map displays various depocentres in the study area. Note most depocentres, apart from the depocentre LM1, in the elongate minibasin domain are located along the west of individual minibasins. (f) Upper Miocene time-thickness map illustrates the development of laterally continuous and symmetric depocentres. Depocentres UM1 and UM2 are marked on the left. (g) Pliocene-Holocene time-thickness map shows the development of asymmetrical depocentres and salt-cored folds. 
(a) Cenomanian-Coniacian topography

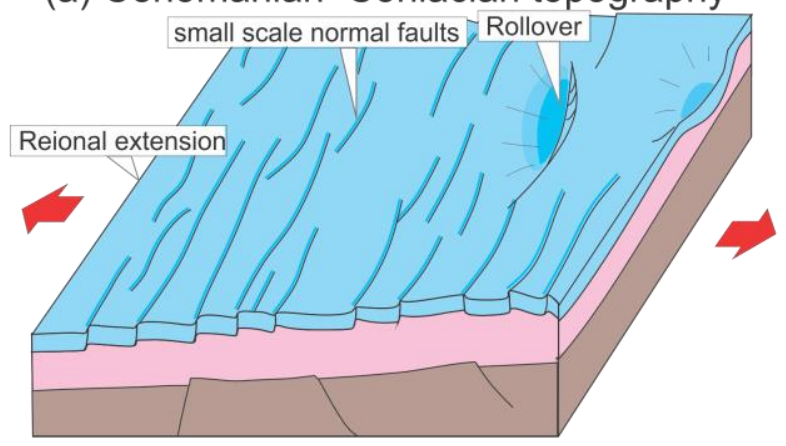

(b) Santonian-Paleocene topography

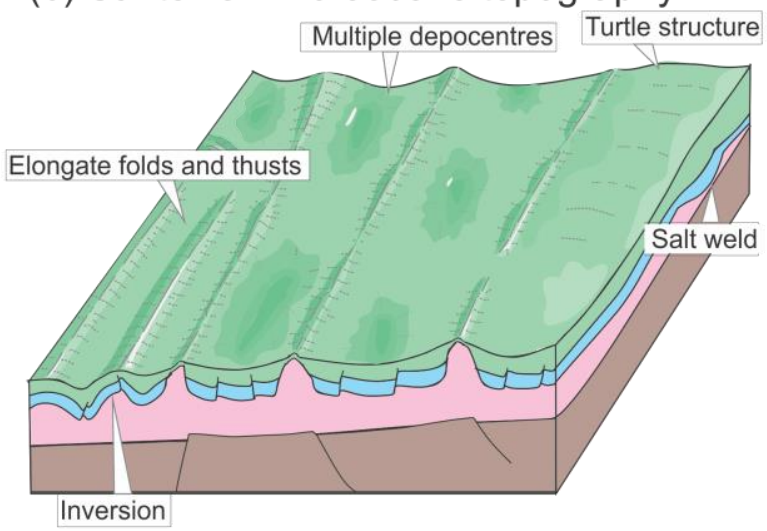

(c) Eocene-Oligocene topography

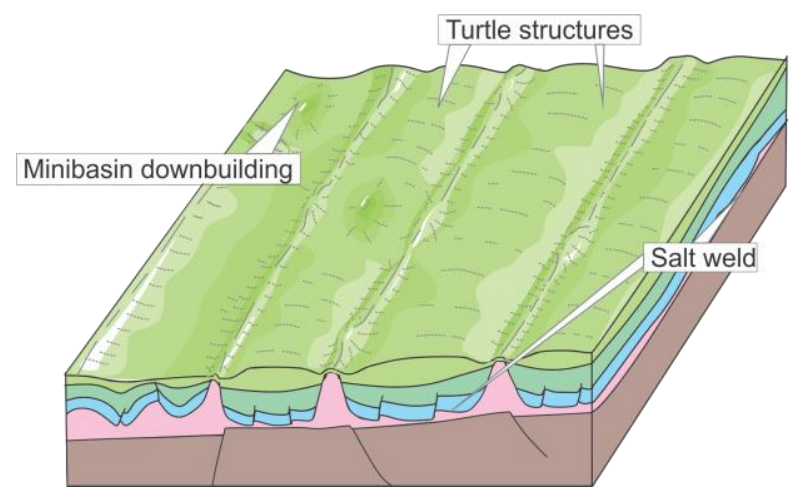

(d) Early Miocene topography

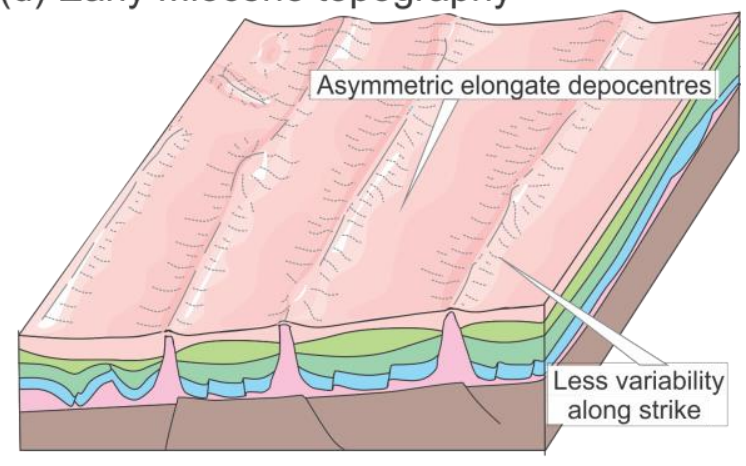

(e) Late Miocene Symmetric elongate depocentres

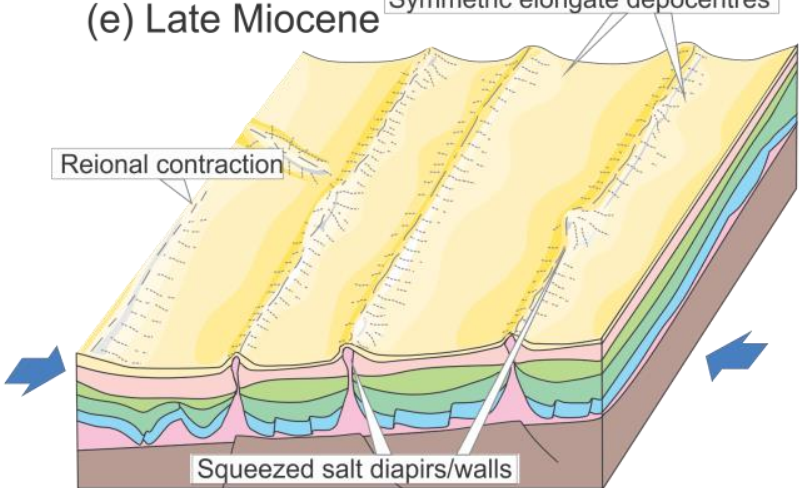

Fig 9. Block diagrams illustrating the development of minibasins and associated salt walls in the study area. (a) Cenomanian to Coniacian. Note the widely distributed normal faults and two large rollovers. (b) Santonian to Paleocene topography, with matured minibasin of turtle structures and unmatured minibasin with multiple depocentres along the strike. (c) Eocene to Oligocene topography. Note the turtle structures dominate the elongate minibasins. (d) Early Miocene topography when the margin tilting force the depocentres to the west of the minibasins. (e) Late Miocene topography with squeezed and uplifted salt walls/diapirs. 

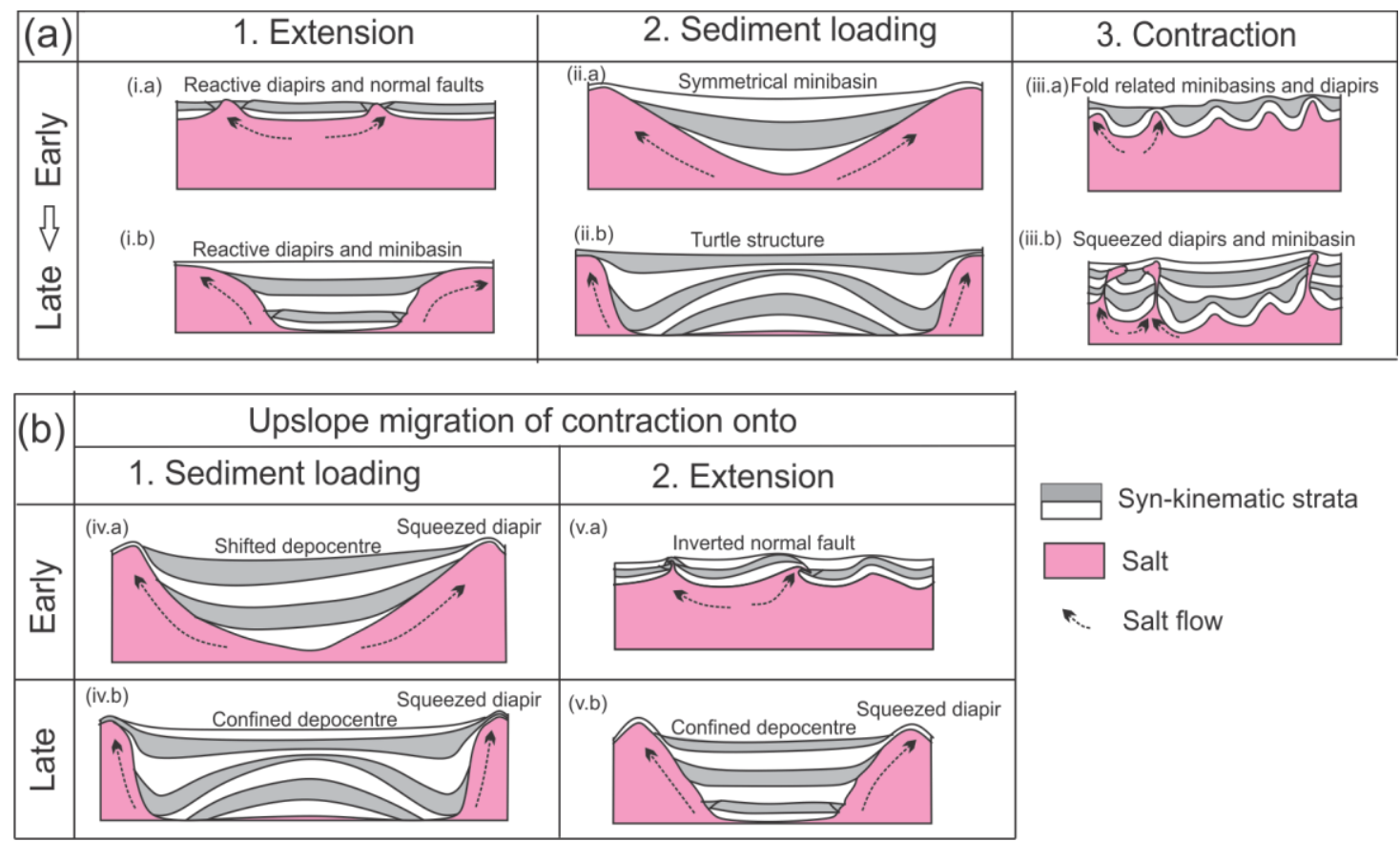

Fig 10. (a) Minibasin geometry and stratigraphy under various driving mechanism and maturity. (i) Minibasin development controlled by extension. Note the extension is partially accommodated by diapir as cryptic extension (i.a and i.b). Modified after Jackson, Vendeville, and Schultz-Ela (1994). (ii) Minibasin development controlled by sediment loading. Modified after Hudec et al. (2009) and Peel (2014). Note the early symmetrical minibasin (ii.a) and more mature, late turtle structure (ii.b). (iii) Minibasin development associated with contraction as early fold- and thrustrelated minibasins (iii.a) are modified by late polyharmonic folds (iiib). Modified after Fort et al. (2004). (b) Variations of minibasin geometry and stratigraphy as the main driving mechanism changes during upslope migration of the contractional domain. (iv) Main control of minibasin evolution changes from sediment loading to contraction. Note the different geometries as the change occurs in early (iv.a) and late stages (iv.b) during minibasin downbuilding. Based on Hudec et al. (2009) and this study. (b2) Main control of minibasin evolution changes from extension to contraction. Note the different geometries of minibasins as the inversion occurs in early (v.a) and late (v.b) stages of extension. 